\title{
From the project for a Passion selon Saint Marc to the Realization of the Canticum Sacrum: The Events Surrounding Stravinsky’s Venetian Commission ${ }^{*}$
}

\author{
Egidio Pozzi \\ Universityof Calabria, Cosenza, Italy
}

\begin{abstract}
The article concerns the commission that was made by the Biennale di Venezia to Stravinsky in the 50s' which led to the composition of the Canticum Sacrum. The discovery of the correspondence between the composer, the artistic director Alessandro Piovesan and the organizers of the Venetian Festival allows to reconstruct the events that led Stravinsky to change his initial plans for a Passion selon Saint Marc in favour of a short Canticum. The objections, which concerned above all the limited size of the piece, were repeated several times by Piovesan, but were all disregarded by Stravinsky. In the light of the eight letters deposited in the Archivio Storico delle Arti Contemporanee (ASAC) of Venice (in Appendix), the circumstances bringing about Stravinsky's refusal can be fully understood. The references to recent studies by David H. Smyth, Akane Mori, and Jonathan Kramer regarding the identification of palindromic and proportional structures in the Canticum, offers further proof sustaining Stravinsky's declaration that to enlarge the piece would have been impossible. These events confirm the composer's unbending determination to undertake a new experimental stylistic direction already tried out in pieces like the Three Songs from William Shakespeare and Agon.
\end{abstract}

Keywords: Stravinsky, Canticum Sacrum, Biennale di Venezia, Passion, analysis

\section{Introduction}

Venice and Stravinsky, a mutual and requited love affair: the city where the composer lived for just brief periods and the one he loved perhaps more than any other. Venice saw the birth of several of his most successful works, including the Sonata for piano, which he performed himself in September 1925 during the Festival of the Società Internazionale di Musica Contemporanea, the Capriccio for piano and orchestra, which

\footnotetext{
* Acknowledgments: This article is an extended version of the research carried out at the Archivio Storico delle Arti Contemporanee (ASAC) during the editing of the Catalogue for the Biennale Musica 1999, whose program included Igor Stravinsky's complete chamber works. The documents (published in Appendix) are deposited in two files kept at the above-mentioned Archive, Fondo Storico, Serie Musica, M4. The first file is labelled "Concerto 13 September - 1956 Stravinsky", folder "Igor Stravinsky"; the other is labelled "Compositori - Igor Stravinsky", folder "Stravinsky - Craft, varie". I would like to thank the artistic director of the Biennale Musica, Bruno Canino, and the director of permanent activitiesMichele dall’Ongaro, as well as the managers of the Archivio Storico della Biennale, the director Gianfranco Pontel and Daniela Ducceschi for their collaboration and for the immense kindness with which they met my requests; without them I would not have been able to trace the documents and letters of Stravinsky. Special thanks to Dr Stefano Piovesan, the son of Alessandro Piovesan, for his help with his father's personal archive. Many thanks also to Elisabeth Dunkl, the librarian of the Istituto Storico Germanico di Roma, and her colleagues, Christine Streubuehr and Roberto Versaci, and to Raffaella Pittaro Pavanello and Lucia Bova for their invaluable help.

Egidio Pozzi, professor, Department of Humanities, University of Calabria.
} 
he conducted in 1934 with his son Soulima as the soloist, and the opera The Rake's Progress, again conducted by the composer at the Teatro La Fenice on 11 September 1951. Venice is also the city where the first performance of many of his sacred compositions was given, including the Canticum sacrum ad honorem Sancti Marci nominis for tenor, baritone, choir and orchestra, performed in St Mark’s in 1956, and Threni: id est Lamentationes Jeremiae prophetae, at the Scuola Grande di San Rocco two years later.

It was for this reason, among others, that the Biennale Musica 1999 decided to dedicate part of its program to a revisitation of Stravinksy's entire chamber output, vocal, instrumental, sacred and profane. ${ }^{1}$ And it was against this background that the present investigation took shape regarding one of the most interesting commissions of the composer's late period, that of the Canticum sacrum, dedicated to the city of Venice and its Basilica; a composition that bears witness to his interest in the music of Webern and Schönbergian serialism during the 1950s. The events surrounding this work, which can now be clearly reconstructed on the basis of the correspondence between Stravinsky and the organizers of the Venetian festival, persistently highlight a particular aspect of Stravinsky as a composer, an aspect that, over and above any stereotyped image of the composer's attachment to economic matters, underlines the strong and clear awareness he had of his own stylistic development.

Stravinsky, as Eric Walter White recalls, had always been very fond of Italy and after the first performance of the Rake's Progress in Venice his visits became ever more frequent. In file M4 of the Archivio Storico delle Arti Contemporanee (ASAC) we find the French text of a talk dating from his stay in Venice in 1956 that the composer probably read on television. During the talk he speaks of his previous visits and expresses the fondness he felt for the city of Venice.

My first memory of Venice dates to 1912. I had come to meet Diaghilew. This first contact with Venice, for me, was absolutely extraordinary. Over the years I have often returned to Venice, and still today the city astonishes me as though I was seeing it for the first time. I was however always led back to Venice for reasons involving music. In 1925, to play my Sonata for piano, that I had just composed; in 1934, to conduct my Capriccio for piano and orchestra, with my son Soulima at the piano; and then in 1937, when I conducted a concert version of my new ballet Jeu de Cartes at the Fenice. Lastly, in 1951, for the premiere of The Rake's Progress, also at the Fenice. And here I am in Venice once again for my Canticum Sacrum, that I composed for the Biennale and have dedicated to the city of Venice in honor of its patron saint, St. Mark.

For the first time I will be conducting in a church, and the fact that this church is St. Mark's Basilica fills me with an indescribable emotion. All of this in Venice, Venice that I love so much! And, let me tell you, no amount of tourism in the world would make me hesitate about coming back.

Igor Stravinsky²

Stravinsky reached Venice with his wife Vera and Robert Craft on 30 July 1956, arriving from Athens,

\footnotetext{
${ }^{1}$ The wish to pay homage to a great composer is not, of course, the sole reason behind the program. In the introduction to the festival catalogue, Bruno Canino and Michele dall'Ongaro explain that "at a time of transformation and stock-taking at the end of the century, we should return from time to time to the to the mainstay of the twentieth century to understand, for example, just how much has remained today of the authentic lesson given to us by the Russian master. Now that the old and much discussed Adornian theses have been exhausted, the Schoenberg/Stravinsky confrontation no longer has any sense, whereas the treasure offered by his chamber music still holds precious secrets that need urgent investigation. The notable lack of musicologic texts dedicated to the chamber music of Stravinsky would also seem in some way to be a call for further attention. (Pozzi, 1999, p. 13).

${ }^{2}$ In addition to these trips a brief stay between the 25 and 27 April 1931 should be added (arriving by hydrofoil from Trieste and involving a visit to the Palazzo Ducale and St Mark’s) and another just as brief in 1955 (17-19 April), when he met Count Alesi, the president of the Biennale, and Piovesan to draw up the agreement for the commission. It should be remembered that Stravinsky wished Venice to be his last home: he is buried on the island of San Michele, alongside his wife and his friend Diaghilev.
} 
after a two day journey on the Mediterranean, a wretched boat described by Vera in her diary (Craft, 1985, p. 180). They were met on the quay of the Bauer Gründwald by Alessandro Piovesan, the organizer of the XIX Festival Internazionale di Musica Contemporanea di Venezia, for a visit that only a few months before had seemed to have fallen through. ${ }^{3}$

Their stay in Venice was to conclude on 13 September with the world première of the Canticum sacrum, conducted by Stravinsky himself. The concert was held in the Basilica of St Mark’s, which had been granted, in the words of a press release of the time, "with the benevolent and exceptional concession of His Eminence the Cardinal Angelo Giuseppe Roncalli, Patriarch of Venice, in view of the special homage of Maestro Igor Stravinsky to the patron of Venice". The Canticum, as we learn from the program notes to the concert, was performed twice, following precise instructions from the composer. ${ }^{4}$ The program, which also included music by Andrea and Giovanni Gabrieli, Monteverdi and Schütz conducted by Craft, ended with the Canonic Variations on Vom Himmel hoch da komm' ich her by Johann Sebastian Bach, transcribed by Stravinsky for choir and instruments. ${ }^{5}$ The Canticum, on a text taken from the Latin version of the Bible, was probably completed in November 1955, as mentioned by the composer in a letter to Dr Ernest Roth, the director of Boosey \& Hawkes. ${ }^{6}$ The performance met with a mixed reception. White recalls that many critics bitterly attacked the work, and echoes the opinion of Craft in saying that: «the critics showed themselves unable to perceive the masterpiece that lay in the work presented to them [...]. The magazine Time was almost insulting: their comment was 'Murder in the Cathedral'» (White, 1983, p. 591). ${ }^{7}$ The piece was not easy listening and the repeat of the performance does not appear to have helped in its understanding as much as Stravinsky had hoped.

Over and above the outcome of the concert, the commission of the Canticum came up against a series of

\footnotetext{
${ }^{3}$ According to Robert Craft, Stravinsky and Piovesan had probably met in the course of the first performance of The Rake's Progress, which took place in Venice in 1951 (Craft, 1982-85, vol. I, p. 259). Alessandro Piovesan (Venice 1908-1958), studied piano and composition in Venice with Gino Tagliapietra; he graduated from the Liceo musicale in Pesaro and enrolled in the composition courses held by Gian Francesco Malipiero. He taught at the Venice Conservatory and from 1940 was the director of the library. He collaborated in several radio programs, before working in 1947 as head of the press office alongside Ferdinando Ballo, the then director of the Festival della Biennale. In 1952, when Ballo could no longer dedicate himself to the Festival due to his commitments with the RAI, the directorship was given to Piovesan, who was believed the only person able to replace Ballo and to maintain the marked propensity towards modernity and the avant-garde that had characterized the previous management. The six festivals organized by Piovesan, between 1952 and 1957, greatly contributed to the knowledge and spreading of contemporary music in Italy. The compositions presented in those years included Schönberg's quartets (in 1953), Britten's The Turn of the Screw (given its first performance in 1954), Gershwin's Porgy and Bess (1955), Hindemith's Kammermusik (1957) and Prokofiev's The Fiery Angel, revived in 1955; in addition, first performances were given of the following works by Stravinsky: the Canticum sacrum ad honorem Sancti Marci nominis, dedicated to Venice and its Basilica, and Threni id est Lamentationes Jeremiae prophetae, performed during the 1958 Festival and dedicated to the memory of his friend Piovesan (AAVV, 1958; Piamonte, 1968).

${ }^{4}$ On 18 October 1955 Stravinsky wrote to his publisher, Dr Roth of Boosey \& Hawkes in London: «[...] Also the Canticum should not be played in an orchestra concert, but only under the best - most intimate - conditions of chamber music. It will last probably not more than 15 minutes and would best be heard twice on the same program» (Craft, 1982-85, vol. III, p. 392).

5 This was not, despite what was announced, a world première, as it had already been performed in Ojai, California, on 27 May 1956. The composer himself also mentions the fact in a letter sent to Nadia Boulanger for Easter 1956 (Craft, 1982-85, vol. I, p. 258). On this matter, see also Stravinsky’s letter to Piovesan dated 3 March 1956 (Appendix Figure A7).

6 «I am sending you today or tomorrow, under separate cover, the fifth and final part (vocal and full scores) of my Canticum...» (letter dated 25 November 1955, in Craft, 1982-85, vol. III, p. 395). Several months later the composer spoke to Nadia Boulanger about the work, adding: «It is short, 16 minutes, and rather difficult; now for the proofs, and corrections! Having finished the Canticum, I have set to work on an instrumental version with choir of J. S. Bach's canonic variations on Vom Himmel hoch da komm' ich her. I have decided to do this and my Canticum in Venice, together with other works of a religious character: Andrea Gabrieli, Schütz, Monteverdi, Gesualdo...» (Craft, 1982-85, vol. I, p. 257).

${ }^{7}$ Further critical opinions about the work can be read in Parente 1956 and Malipiero 1966. Favorable opinions were however expressed by Mariani 1976 and Mila 1983a.
} 
problems that, until the very last moment, placed the performance in doubt. The discovery of certain letters written by Stravinsky, until now published only on Catalogue for the Biennale Musica 1999 and held in the ASAC, makes it possible to reconstruct the original intentions, together with the problems that arose and the relative solutions, and at the same time clarify certain aspects regarding the organization of the concert which are not very convincing in the biographies published to date.

Of particular interest are not only the long-drawn economic negotiations that Stravinsky had with the directors of the festival, but more especially the initial project that he proposed to the Biennale, a project that was at first met with considerable enthusiasm. The eight letters written by Stravinsky which deal with the commission of the Canticum cover a period of four years, from 1953 to 1956. The first two contain the composer's thanks for the performance of the Cantata and his negative reply to the request to present the first performance of the Septet at the Biennale. The three letters from 1954 deal with the early stages of negotiations, where certain basic economic questions are set out and where Stravinsky refers several times to the idea of writing a large-scale composition, namely a Passion selon Saint Marc. The three letters written between 1955 and 1956 (9 July 1955 to Alesi, the President of the Biennale, 3 March to Piovesan and 28 March again to Alesi) go into the matter in more detail and lead one to suppose a series of problems and misunderstandings that were not only to bring about a slowing down of the negotiations but also to raise the risk of the project being completely abandoned.

Although these letters clearly describe the economic and artistic problems involved in the type and size of the composition that they intended to perform in the most important church in Venice, a complete reconstruction of the events inevitably requires reference to other documents, most of which are deposited in the Venice Archives.

\section{The First Negotiations}

Since December 1952 Prof. Giovanni Ponti and Alessandro Piovesan (respectively the president and secretary of the Biennale) had been asking Stravinsky's permission to include the world première of the Septet in the 1953 edition of the Festival, along with the Cantata. ${ }^{8}$ Even though Robert Craft supported the scheme and several times expressed his enthusiasm about being able to conduct a first performance of a work by Stravinsky in Venice, the project was not fulfilled. ${ }^{9}$ The reasons for the refusal are contained in the first two letters kept at the ASAC (Appendix Figures A1 and A2): in 1953 the piece was still not finished and in June of that year Stravinsky resolved not to go to Europe. However, making the most of the good will shown by the composer, in spring 1954, when Stravinsky was giving a concert in a festival in Rome, ${ }^{10}$ negotiations were

\footnotetext{
8 "Illustrious Maestro, Following the first tentative enquiries made by our colleague Signorina Emilia Zanetti, I would like to confirm our deepest wish to be able present an instrumental piece by you in the Festival of September 1953. Both the Cantata on Elizabethan texts and the Septet, of which we would like to give the first performance, would in themselves constitute the precious material for an instrumental concert dedicated to you. Such a project represents the height of our aspirations and we are certain that your fondness for our institution and for the city of Venice will make you favorable towards its realization. Moreover, we nurture a secret hope of being able to see you in Venice for the occasion [...]” (ASAC, from the Italian version of the letter of 7 December 1952 from the President of the Biennale to Stravinsky).

${ }^{9}$ In a letter to his wife dated 6 April 1953 Stravinsky mentions that Craft was hoping to conduct the first performance of the Septet in Venice, on the assumption that discussions for a first performance at the end of January 1954 with John Thacher, the director of Dumbarton Oaks, would come to nothing. This is confirmed in a letter from Craft to Piovesan dated 20 March 1953, where he agrees to conduct a concert at the Venice Festival and goes on to say that they might well be able to obtain the first performance of the Septet for the Biennale, even suggesting the type of approach that should be made to Stravinsky.

${ }_{10}$ In April 1954 Stravinsky went on a tour of various Italian cities; the meeting in question probably took place during the concert held on 14 April (Craft, 1985, p. 172)
} 
reopened regarding a commission for the 1954 Biennale or for that of the following year. Piovesan sums up the points discussed during the meeting in a letter sent to the composer on 13 May 1954:

Venice, May 13, 1954

Dear Maestro,

I have let some time pass before returning to the project that we discussed in Rome in mid-April, on the evening of your splendid concert. In the meanwhile, I have spoken with our Minister, Giovanni Ponti, and the Mayor of Venice, Prof. Angelo Spanio, who needless to say were overjoyed at the thought of having you in Venice once again. All that remains for me now is to confirm the essential aspects of your special collaboration with the upcoming Biennale Festival.

The concert in the Basilica, that will most likely take place in September 1954 or 1955 (depending on any changes in your own engagements, as you yourself have told me), will include a first part dedicated to music by Andrea and Giovanni Gabrieli and a second part set aside for one of your vocal-instrumental works on texts from the Gospel or the Bible. On this matter, I believe that the duration of the piece, which will be dedicated to the Biennale and will receive its world premiere performance here, should be somewhere between thirty and forty minutes. This is a very flexible duration, and will be defined only by the structural requirements of your work.

While kindly requesting Maestro Robert Craft to collaborate in conducting the first part of the concert, I would like to ask you, dear Maestro, to inform me as soon as possible as to the details of a binding agreement that takes into account your twofold collaboration: some fees will thus be allocated for the first performance of your work; other fees will be provided for your direct collaboration as Conductor.

You are already well aware of the financial hardships that the Biennale is faced with, struggling as it does, after so many years, with innumerable difficulties in its commitment to contemporary art. I can only appeal to your exquisite kindness and even, I would say, to a sentiment of spiritual collaboration that expresses your affinity with the ideals of our cultural activity. In all sincerity, I anxiously await your response and hope that our artistic relation will be fully and definitively defined as soon as possible. In the meantime, dear Maestro, our President and I remain faithfully yours.

The Director of the International Music Festival (Alessandro Piovesan) $^{11}$

Stravinsky's reply was quick in coming: in a letter of 21 June he informs Piovesan of his financial requirements and sets the deadline for the drawing up of the contract. A clear picture of the terms of the negotiations between the composer and the organizers can best be obtained by reading the document in question (Appendix Figure A3):

Hollywood, California, June 21, 1954

Air Mail

Mr. Alessandro Piovesan

Director of the Venice Biennale International Music Festival

Ca’ Giustinian, Venice, Italy

Dear Sir,

I have just returned home at the end of my concert tour in Europe, and only now am I able to respond to your kind letter of May 13. As I told you verbally during our meeting in Rome, your project for a concert in St. Mark’s Basilica under the auspices of the Biennale deeply interests me. Considering the things we have already sketched out, i.e. a program that includes a first part dedicated to a work by Gabrielli [sic] (to be conducted by Robert Craft) and a second part that would be a premiere of a new work of mine (conducted by myself), I plan on composing a work lasting from 30 to 40 minutes for this occasion (as you yourself have indicated) on a text from the Scriptures (Old or New Testament). This work would be for choir, solo voices and various common instruments, but would not necessarily require a complete symphony orchestra.

11 ASAC, copy of the letter from Piovesan to Stravinsky dated 13 May 1954. 
I would compose this work for the Biennale, to which it would be dedicated. Financially speaking, the project would be defined as follows:

I/- The total cost of this commission for the Biennale would amount to $\$ 12,000$.-- (payable in the USA in Dollars) and would be settled in two tranches:

a/- an initial payment of \$6,000.-- prior to 1 October 1955 , and before I begin work on this composition, which I will reserve this date;

b/- a second and last installment of $\$ 6,000$.-- on 1 August I956, against delivery of the finished work, by myself, to my editor, Boosey \& Hawkes.

2/- The price of \$12,000.-- indicated above exclusively covers the commission. My conducting the work at the Venice Biennale in September 1956 will require a special fee of \$3,000.-- (payable in the USA in Dollars) transferred prior to the public performance.

Kindly discuss this project with the authorities involved, and let me know as soon as you can if you agree with it because, as I have told you, my work schedule is currently so full that I am forced to define these details now, as early as two years in advance.

Very sincerely

Igor Strawinsky

It is curious to note the precision and detail with which Stravinsky stipulates his economic requirements and the terms of the contract, as well as the particulars of the artist project foreseen in the agreement. His intention to compose a large-scale work is evident right from the start and there is little doubt that it was this aspect that most influenced the directors of the Biennale in their evaluation of the project. Proof of this can be found in a letter from Piovesan to Stravinsky dated 30 October 1954 in which, on the basis of information given by Craft, direct reference is made to a St Mark's Passion: ${ }^{12}$

30th October 1954

Mr. Igor Strawinsky

1260 North Westerly Drive

HOLLYWO0D -Cal.

Dear Sir and Maître,

Only in the forthcoming month of November the competent Ministry for Entertainment will decide on the appropriation of funds for next year's Festival. I have been waiting anxiously for this decision and I feel I must gain time notwithstanding the bureaucratic rules would leave me to wait for the official announcement of the funds decided upon, I am taking the liberty of writing you to inform you that I will engage in every effort in order to realize the ideas I spoke to you about last spring in Rome.

It is of course only these financial difficulties that have to be overcome, that is that out of the never entirely sufficient funds that are assigned for the organisation of the Festival. I have to set aside the amount required for the concert dedicated above all to your evangelical composition. I have now heard from friend Zanetti, who also collaborates in the Festival, that she has been told by Mr. Robert Craft that you at present composing a "Passion according to St. Mark”.

The subject is splendid and gives me hope and enthusiasm in succeeding to overcome the financial problems. I would only like to receive your confirmation that the piece is in effect a "Passion according to St. Mark". In this case I shall have the possibility of enhancing the particularly symbolical character of the worw and thus obtain that which is required to set up your opera in the very finest manner.

I would like to take this news to Rome with me and I shall be much obliged if you will write to me or get somebody to write to me your confirmation. I trust you have heard of the great success obtained by the Festival I organised last September. International press has been unanimously laudatory. And this is an excellent change for me to win the financial

\footnotetext{
${ }^{12}$ Other letters regarding the Venice commission can be found among the documents published by Robert Craft relating to the period in question. In a letter dated 30 December 1954 Nabokov asks Stravinsky if it is true that he is writing a St Mark's Passion for Venice (Craft, 1982-85, vol. II, p. 391). In a letter to Nadia Boulanger on 5 February 1955, Stravinsky repeats the idea of wanting to write a "short Passion", but only after signing the contract (Craft, 1982-85, vol. I, p. 257).
} 
battle! I am looking forward to receiving your kind news at the earliest.

With the best greetings and regards from the "Biennale" and from myself,

Piovesan was to come back to this matter later in a letter dated 29 November 1954:

\author{
Mr. Igor STRAWINSKY \\ 1260, North Wetherly Drive \\ HOLLYWOOD, 46 - California
}

Dear Maestro,

I am pleased to inform you that the Artistic Committee will meet on December 3 in Rome to discuss and define the program of the 18th Festival.

Despite the fact that very few days remain before this date, I would like to assure you that I have already spread the word, in the Venetian musical circles that are the closest to me and that are the most interested in the prestige of our organizational efforts, as to your probable presence in Venice, with a religious work dedicated not only to the Biennale Festival, but also, one could say, to Venice.

I therefore wish to confide to you that I could be very effective in intensifying this state of high expectation, and thus obtain further collaboration from the other public and private bodies responsible for the financial contribution necessary to cover the costs of the performance, in the event in which you were to settle on a work based on the Gospel of St. Mark. I have already been able to sound out various reactions, and I can tell you that a St. Mark "Passion”, by way of its singular coincidence with our own patron saint, would enormously favor this delicate phase of collaboration and greatly contribute to concretely completing this long-desired project.

I have also succeeded in getting word of this possibility through to our Minister, Giovanni Ponti (who for many years was the President of the Biennale), and I was able to note his lively interest for a Passion according to the Gospel of St. Mark.

A performance of this kind would no doubt call for both soloists and a choir; in any case, any musical work on religious texts would not exclude a similar ensemble.

I earnestly hope that your choice will fall on a "St. Mark's Passion", and will be proud to give you official information on this matter in the near future. At any rate, in order for you to know what to expect, I would like to inform you that it is possible for a specific and detailed contract to be written before Christmas.

I hope to receive good news from you soon, dear Maestro, and in the meanwhile I remain sincerely yours.

THE SECRETARY OF THE INTERNATIONAL MUSIC FESTIVAL

(Alessandro Piovesan) $^{14}$

It was, however, Stravinsky himself who confirmed the hopes of the organizers in Venice, not so much in the letter dated 5 November 1954 (Appendix Figure A4)—whose main scope was to accelerate the drawing up of the contract-as in that of 4 December of the same year, once more to Piovesan (Appendix Figure A5):

December 4, 1954

Air Mail

Mr. Alessandro Piovesan

Director of the Venice Biennale International Music Festival

Ca’ Giustinian Venice, Italy

Dear Sir,

I recently received your kind letter of November 29 and am happy to see that not only do you share my idea of

13 ASAC, copy of the letter from Piovesan to Stravinsky dated 30 October 1954.
14 ASAC, copy of the letter from Piovesan to Stravinsky dated 29 November 1954 
composing a "St. Mark Passion" (on the Latin text of the Gospel), but that the various public personalities to whom you have explained this project seem to have their hearts set on it as well.

Let us agree then that as of the present this "Passion" must be the object of your negotiations and our possible contract.

Needless to say, I am not prepared to give you the details of such an important composition at once, but as a general outline rest assured that the orchestra will be modestly sized (as you know, I now compose less music for "orchestra” and more chamber music). For the soloists and the choir, nothing will go beyond a reasonable limit.

All my best wishes for the complete success of your negotiations with the various bodies involved.

Very sincerely Igor Strawinsky

P.S. If this project is carried through, I would be particularly glad to dedicate the work simultaneously to the City of Venice and the Biennale.

\section{From the Project for a Passion to the Realization of the Canticum}

Piovesan's hopes that the inevitable financial problems would soon be resolved turned out to be too optimistic; it was not until 25 March 1955 that he was able to send Stravinsky a preliminary draft of the contract, based on the requests the composer had made in his letter of 21 June 1954 (Appendix Figure A3). ${ }^{15}$ In the same year Stravinsky and Vera came to Italy. By mid April Stravinsky was in Rome to inaugurate his wife's exhibition at the Galleria Obelisco, and on the 18 he was in Venice to check out the acoustics of the churches della Salute and di Frari, in case St Mark's was not available for the concert planned for the following year. While they were in Venice Stravinsky had lunch with Piovesan and count Massimo Alesi, the President of the Biennale (Craft, 1985, p. 177). The composer probably brought up several fundamental questions regarding the commission and some of these were repeated in a letter of 9 July 1955, addressed to Alesi (Appendix Figure A6).

In the meantime, without waiting for the negotiations to be concluded, Stravinsky had begun the composition for Venice. In a letter dated 27 July 1955 he informed his publisher of the title he had chosen, the number and details of the parts, and the sources of the Latin text. By September the piece was almost finished, as can be gathered from a letter from Craft to Piovesan, where the young conductor gives the title chosen by Stravinsky, together with his personal impressions: «[...] The Canticum sacrum ad honorem Sancti Marci nominis (this is the title) undoubtedly represents the most extraordinary composition of the last decade. I hope the organ at St. Mark's is well tuned and in good condition, as the organ part is very important [...]». ${ }^{16}$

On 18 October, after receiving requests to perform the Canticum in a London church, Stravinsky confided to Roth, the director of Boosey and Hawkes, something that he foresaw would perhaps be a problem of no small count: the composition prepared for Venice would not be the promised Passion, but a Cantata probably lasting no longer than 15 minutes. The news also reached Piovesan, since in a letter to Roth, after speaking of certain problems regarding the balance of the costs sustained for Prokofiev's The Fiery Angel, performed in the 1955 Festival, and for the radio rights, he brings up the matter of the length of Stravinsky's new composition:

[...] I am personally worried about the possible length of the composition Stravinsky is writing for us. From my point of view as organizer, it is inevitable that I should be concerned about the contents of the Stravinsky program, conducted by the composer himself. Alongside the new composition, then, there will have to be another of the Maestro's religious works.

\footnotetext{
15 The draft of the contract contained additional formal and administrative clauses that were contested by the composer, as confirmed in a letter he sent to Alesi on 9 July 1955 (Appendix Figure A6).

16 ASAC, from the Italian version of the letter from Craft to Piovesan dated 12 September 1955.
} 
Maybe, if Stravinsky agrees, the Cantata, which lasts about half an hour. In that case, in order to give a well balanced program the concert should start with the Cantata, followed by an interval, and then Stravinsky's new piece, which should in any case last at least 40 minutes to fill out the program, otherwise we shall have to make do with just an hour of music.

As a musician I know that it could work well as it stands, seeing that a composition cannot be judged on its length, but as an organizer I must tell you that we need to satisfy an audience that considers it an exceptional evening to see on the podium of La Fenice, or on the altar of a Church, the maestro Stravinsky conducting his new work dedicated to the Biennale. I beg you, dear Dr. Roth, to do everything within your means about this detail, which is an important issue, and as far as is possible, to help me by using your influence over the Maestro. [... $]^{17}$

In his reply to this letter Roth officially informs Piovesan of the latest news about the length. The piece, still not finished, would last around 15 minutes and would be particularly complex; as a consequence Stravinsky suggests a repetition of the same Canticum at the start of the second part of the concert as well as certain changes to the evening's program.

Boosey \& Hawkes November 16, 1955

Mr. A. Piovesan,

La Biennale, Venice

Dear Mr. Piovesan,

I have just received a letter from maestro Strawinsky, answering the questions that you put forward to me:

He estimates that the duration of the CANTICUM SACRUM will be approximately 15 minutes, but it goes without saying that he has not completed it as yet, and I myself only today received the 4th part. The work is shorter than you believe. Strawinsky has however proposed the following program:
l. RICERCARE for 4 trombones
- Andrea Gabrieli
2. a) PSALM for 5 voices
- Heinrich Schuetz
b) MOTET no. 14 for 7 voices
- Carlo Gesualdo
c) LAUDA JERUSALEM for 7 voices
3. CANTICUM SACRUM
- Claudio Monteverdi
- Igor Strawinsky
entr'acte
4. CANTICUM SACRUM
- Igor Strawinsky
5. CHORAL VARIATIONS "VOM HIMMEL HOCH, DA KOMM'ICH
- J .S. BACH, arrangement by
- I. Strawinsky
HER" for instrumental ensemble

You can thus see that Strawinsky wishes to repeat the CANTICUM. Judging by what I have seen until now, it is a very complicated and severe work and I believe that it would be highly desirable for it to be repeated in concert. What is more, you can see that he intends to make an instrumental arrangement of the work by Bach, that has a duration of roughly 25 minutes.

Strawinsky does not want to conduct his CANTATA, because it is not a religious work, and he finds that the SYMPHONY OF PSALMS would not go well with the CANTICUM (probably due to their differences in style).

I therefore ask you, dear Mr. Piovesan, to consider the proposals made by the Maestro and make any observations you wish. Could you fix the date of the concert already?

I am looking forward to your kind reply.

Your sincerely

Dr. E. Roth ${ }^{18}$

\footnotetext{
${ }^{17}$ ASAC, from the Italian version of the letter from Piovesan to Roth dated 25 October 1955.

18 ASAC, letter from Roth to Piovesan dated 16 November 1955.
} 
The difficulty of the situation is, at this point, quite clear. At first Piovesan expresses his deep concern to Roth and urges him to do something to persuade Stravinsky to make the piece longer:

Dr. Roth

Messrs. Boosey \& Hawkes

295 Regent Street,

LONDON W.I.

Dear Dr Roth,

I have received your kind letter of the I6th of Nov., and I have read over and over again the news that worries me: the length of the Strawinsky composition is very short. The situation from this point of view is delicated and complicated. I quite understand in a composition contract with a musician like Strawinsky one cannot fix the length, and on the other hand a work of art goes beyond any discussion on its length or brevity. But you will agree with me that there are other considerations of an exterior nature yet important depending also on the length of a composition.

In other words even the length has its value in determining the engagement undertaken by the artist in giving substance and consistence to our first evaluation; these considerations may be useless, but they are necessary to show you why under the circumstances and in view of the responsibility I have taken also towards my President, I find myself in an uneasy position.

The Maestro of course had never fixed the length: at first we had talked of a Passion according to St. Mark, which later became a "Cantico". It was our intention to occupy the first part of the programme with this "Cantico" to be repeated in the third part, and in the middle we were to decide whether to include Strawinsky's Cantata, the Mass of the Psalm Symphony.

Personally I would not mind considering the possibility of including music of the old Venetian school, but on this point I wish meditate more at length before giving you a reply or making a proposal; I am thinking of music by Gabrieli or Schutz or Monteverdi, better still if orchestrated by Strawinsky.

Even this is an important problem about which I shall write to you in a few days. As you understand what worries me just now is the length of the sacred Canticum. Would it not be possible with great tact to point out to the Maestro that an international interest will all be looking forward to this new work of' his? Many people will come from abroad to hear the Canticum; many international critics will be in Venice for that first performance. Do you not think, Dr. Roth, that in such a case the length may have its importance in the artistic event that might even weigh on the esthetic values of the work?

If there are four parts could one ask Strawinsky to write a fifth? In order to have at least 25 minutes of music? The Cantata also lasts 25 minutes.

I am trusting entirely to your ability, diplomacy and tact. I shall be in Rome next week to make arrangement with the Italian Radio and settle whether the Strawinsky soiré will be broadcast with Venetian executors or by the Radio executors.

I shall let you know the exact date of the concert. And I have to thank for the friendly solution of the copyrights.

With my best regards, I am, dear Mr. Roth

Yours sincerely

(Alessandro Piovesan) $^{19}$

Even though Roth shared Piovesan’s misgivings, ${ }^{20}$ and despite the strong protests most probably sent by

\footnotetext{
19 ASAC, copy of an undated letter from Piovesan to Roth, probably from the end of November 1955, with the instruction in the Italian version, "please translate into English and send as soon as possible".

20 “Dear Maestro Piovesan, [...] quite frankly your letter does not surprise me. The news that Stravinsky's new work only lasts 15 minutes came to me as somewhat of a shock, as it did to you; but as you yourself say, the quality and importance of a piece cannot be judged by its length. After all Stravinsky has a technique that, in my opinion, does not lend itself to large-scale works. On the other hand, I fully understand that you (like me) were expecting a more representative work for the occasion. You know how difficulty it is for me to influence Stravinsky, but I promise I shall do my best; in the meantime you could clarify your ideas about the program, as suggested by Stravinsky. At present the Canticum has 5 parts, but all the parts put together last 15 minutes. I'll let you know as soon as I have a reply from Stravinsky [...]" (ASAC, translated from the Italian version of a letter from Roth to Piovesan probably sent on 20 December 1955).
} 
the Biennale, represented by its President, ${ }^{21}$ there was nothing left to do than to accept the new conditions. Piovesan wrote to Roth:

Venice, 5 February 1956

Dear Doctor Roth,

I am moved by your kind collaboration. I believe however that there is nothing left to do that will be able to change the course of events. I cannot imagine that Stravinsky will take up the matter again and try to lengthen a score that he considers virtually complete. Besides, there is nothing in our contract that can force such a request, since as always the contract does not set any limit to the length of the composition that was to be written for us. Stravinsky kept saying that he would write a composition lasting 30/40 minutes, but my Administration did not think of inserting a time limit, as we were all convinced that he would write a Passion as first agreed. Now it seems that there is nothing else for us to do than to count on Stravinsky's revisions and try to modify the program originally sent to me, and improve it.

In the first part, following Stravinsky's instructions, you suggested four religious compositions by Gabrieli, Schütz, Gesualdo, Monteverdi. If it were possible to remove the Gesualdo and perhaps replace it with something by Giovanni Gabrieli or another piece by Monteverdi or by De Rore of the Venetian school, we would be able to achieve a program, at least in the first part, that would be much more balanced and stylistically coherent. ${ }^{22}$

[...] Regarding Bach's Choral Variations, orchestrated by Stravinsky, I assume it is a work that the Maestro is preparing especially for Venice and that at least in this way it will help compensate for the other troubles. I am comforted by this thought. The second piece based on Bach is not foreseen in our contract, but seeing that his inspiration ended at a quarter of an hour I think that Stravinsky has done this in order not to disappoint us completely; I must, in any case, confess one thing to you immediately: there is no way that I could obtain any payment additional to that of the contract. If Stravinsky is expecting any extra money, it would be a disaster for us all. [...] At the moment, for my next Festival, I have only the Stravinsky concert, for which the management has promised a subsidy seeing that there is a contract. But I certainly cannot entrust the fortunes of the Festival to a single event. There is no need for me to express my indebtedness to your friendship and your understanding. I know how sincerely you are able to appreciate our serious problems.

[...] Dear Doctor Roth, once again I send you all my thanks for your most useful help and my very best wishes.

Alessandro Piovesan ${ }^{23}$

It may well have been Roth's mediation, spurred on by the pleas of Piovesan and mentioned in another

\footnotetext{
21 “Illustrious Maestro, Maestro Piovesan, the organizer of the International Festival, has given me the latest news about the preparations for the concerts this September and has informed me that you have delivered your work destined for the Festival to the publishers Boosey \& Hawkes. This has been confirmed by the director of the publishing house himself, Dr Roth, who has underlined the fact that the composition lasts around 15 minutes. It should come as no surprise to you to learn that I am forced to consider the importance of the length even though I am well aware that it bears no relationship to the quality or originality of the work of art. But as President of the Biennale I need to assess all aspects of the economic conditions and I confess that on this particular detail, which is meaningless with respect to the work of art, I am in two minds, considering that the length of a piece also carries its own symbolic prestige. I am thus thinking of the possible reaction of the members of the Administrative Board of the Biennale when they examine the financial side of the concert and discover that the greatest bulk of the budget for 1956 has been invested in your invitation to the Biennale, Maestro, an invitation that greatly honors us and will lend new prestige to our Festival. I would kindly ask you to put yourself in the part of the listener and also of the press who, of all the coming concerts, are giving most importance to this sacred composition written especially for Venice. Do you not think that the fact that the composition will be over in a quarter of an hour may have an influence not so much on the evaluation of the work itself, but rather on the significance it assumes in the concert which is, I repeat, for us the most important of the whole program (ASAC, from a draft version of an undated letter to be sent to Stravinsky, probably written in December1955-January 1956).

22 The removal of the piece by Gesualdo should not, therefore, be generically put down to a contestation between Venetians and Neapolitans, as stated by White both in his monography on Stravinsky and in his entry of the same name in the New Grove Dictionary of Music \& Musicians, but rather to the need for stylistic coherence, by accompanying Stravinsky with composers exclusively from the Venetian school.

${ }^{23}$ ASAC, from the Italian version of the letter from Piovesan to Roth dated 5 February 1956.
} 
letter dated 14 February, ${ }^{24}$ that eventually helped resolve the problem. Two days later a brief note refers to a "resolutive" letter of 11 February that had been sent to the festival organizer by the composer.

Boosey \& Hawkes

16th February, 1956

Dear Mr. Piovesan

Strawinsky has just sent me a copy of his letter to you of the 11th February. This is really a human touch of the great man and I hope you will feel as relieved as I do. No doubt I shall hear your reaction.

I am, with kindest regards,

Yours sincerely

DR. E. Roth ${ }^{25}$

Although there is no trace of the letter of 11 February either in the Venice Archive or among Piovesan's personal documents, its contents can be quite clearly understood from the letters that ensued. Stravinsky appears to be fully sympathetic with the firm but realistic position taken by Piovesan and shows his willingness to meet the needs of the Biennale not only by replacing the piece by Gesualdo, but even going so far as to accept less money for the commission. The news of the reduction in the composer's fee can be deduced from the drafts of two letters from Piovesan, one to Roth (17 February 1956) ${ }^{26}$ and the other to Stravinsky (24 February 1956), ${ }^{27}$ but it is clearly spelled out in the draft of a letter, stored in the ASAC, that the president of

\footnotetext{
24 "Dear Signor Piovesan, Many thanks for your letter of the 5th. I perfectly understand all the difficulties of which you inform me but, as you see, Strawinsky is a man of very strong temperament and difficult to move once he has decided on a thing. However, I have written to him immediately and suggested that he might agree to including his Mass, but that in any case the Gesualdo would have to be replaced by one of the Venetian composers, as you mentioned, and I strongly urged him to make this concession, so I hope that he will and I will let you know as soon as he writes to me. I don't think he intended to ask for a fee for the Bach Variations, which after all you had not commissioned, but it will certainly be your première and I have written to Strawinsky for confirmation that he will not ask for a special fee. Thus at least this difficulty will have been overcome [...]" (ASAC, from the Italian version of the letter from Roth to Piovesan dated 14 February 1956).

25 ASAC, letter from Roth to Piovesan dated 16 February 1956.

26 "Dear Doctor Roth, I do not know how to express my gratitude for your precious collaboration. The delay in the payment of the 6/milioni [sic] dollars to Stravinsky was absolutely not due to any possible reservation about the brevity of the composition. Nobody at the Biennale, I believe, would ever have assumed such an unpleasant and absurd stance towards Maestro Stravinsky. [...] I am very relieved by your news and all the more so on learning that Stravinsky has accepted a reduction in the amount in the contract and I am certain that having accepted this reduction he will not ask anything for the variations on Bach's Choral. I can now look forward to being able to dedicate myself entirely to the organization of this concert, especially as my President has hopes of being able to use St Mark's [...]” (ASAC, from the Italian version of the letter from Piovesan to Roth dated 17 February 1956).

27 "Dearest Maestro, Following my telegram of 17/2, I would like, above all else, to assure you that my silence was not an act of psychological cowardice: I found myself in a difficult position and I was taking time to try every way out and to restore the necessary calm. It was really a difficult situation: the board of administration that funds the concerts and has the right to discuss every problem on concrete grounds, pointed out to me that also the length of a musical composition on which the particular interest of a concert is based, can, from a given point of view be susceptible to practical considerations; as far as I am concerned, my mentality and education as a musicologist allow me to find no connection between the length and the quality of the work, that is to say no relationship between worth and price. It is a discussion founded on dialectic quibbles; and, as always happens, those who supply the money have the advantage in any dispute. I spoke of these difficulties to Dr. Roth and avoided taking any side in the discussion while waiting for the problem to break out of its deadlock. And in the end it was you, illustrious Maestro, who with your delicate intuition and discernment released us from the deadlock with such spontaneity and understanding; and thus every difficulty was automatically overcome and harmony was restored between the financial exponents and the artistic organizer. I feel I should stress once again that during the discussion the management of the Biennale had never shown any reserve about sending the 6.000 dollars; the delay in depositing the sum was firstly because the meeting of the Board of Administration was held in Rome, as I mentioned in my telegram; secondly, as unfortunately happens sometimes, because sufficient funds were lacking at that moment. I hope that in the meantime you have heard from the bank about the payment being made. The Board of Administration is now preparing the contract that you yourself approved and which contains no points requiring discussion [...]" (ASAC, from the Italian version at the of the letter from Piovesan to Stravinsky, marked "please translate into English”).
} 
the Biennale sent to Stravinsky on 14 March.

Dear Maestro,

On returning from Rome I was able to read your most kind letter to the organizer of the Festival, a letter that showed us the full extent of your deep and sensitive understanding. In this way all difficulties have been overcome and the organizer will be able to work with the necessary tranquillity that had been disturbed by the points raised by the Board of Administration.

I think that this exchange of letters will be sufficient to ratify the new financial terms that you set out in your letter and which are summarized as follows:

a) you will pay me on 1 April, the sum of 5/thousand dollars. This sum will be paid to me and transferred immediately to my personal account [...];

b) as soon as Boosey \& Hawkes send you the material, you will pay me a further sum of 5/thousand dollars. This sum will be paid to me and paid immediately and directly into my personal account [...].

These two payments, amounting to a total of 10/thousand dollars will cover:

- my commission and the rights for the première at the Venice Biennale, in September 1956, and also my fee for conducting the whole program of the world première at the Venice Biennale, in the same September 1956.

I confirm, illustrious Maestro, that the operation regarding the payment of 6/thousand dollars has already been in course since 24 January. I therefore consider that this sum will be paid to you by 1 April. I would, however, ask you for a small variation regarding the second payment; that is, if you would accept that at least part of the sum of 4/thousand dollars should be paid at the moment of your performance in September in Venice. This is in order to satisfy the Board of Administration that a norm is being respected whereby the fee for a performance is paid at the moment of the actual performance.

I hope that this variation will not disturb your financial arrangements.

I send you once again my deepest thanks, and look forward to receiving your confirmation and to seeing you in Venice in September.

Yours most sincerely The President of the Biennale ${ }^{28}$

Definitive confirmation of the favorable outcome of negotiations is found in a letter from Stravinsky to Alesi dated 28 March 1956 (Appendix Figure A8) in reply to the above letter:

President of the

Venice BIENNALE

Count Massimo Alesi

Venice, Italy

Hollywood

March 28, 1956

My dear Count,

Your letter of March 14 has arrived only now. Judging by its contents, we largely agree. Nonetheless, it appears to be necessary for us to agree once and for all on the following points:

1- As regards the first payment (on 1 April) you must urgently write to the director of the Bank of America, Sunset-Clark branch, giving him your own formal instructions (in English) in order for him to transfer the money to my account as soon as it arrives here. Without these instructions, the amount would remain blocked as a deposit and guarantee, which is not in line with the terms of our new agreement.

2- As for the final settlement, I find that your request to wait until the moment of the premiere performance is excessive. In fact, the sum in question does not correspond to my fee (given that I will now conduct the work free of charge) but to the remainder of the price of the commission. Nevertheless, I understand your situation as regards the Board of Administration, and I propose the following compromise: a) you commit yourself to inviting Robert Craft and paying him \$400.- for him to conduct the pieces composed by the old masters in my program. Thus, I would strictly reserve myself for my own CANTICUM SACRUM and for my transcription of Bach. b) In exchange for this, I will accept that the final payment be carried out ten days before the date of my concert. c) This concert will take place no later than 20

\footnotetext{
${ }^{28}$ From the Italian version kept at the ASAC of the letter from the President of the Biennale to Stravinsky.
} 
September, and the exact date will have to be given to me by April 15 at the latest.

Please be so kind, dear Count, as to send me an answer as quickly as possible, because I confess that I am distressed to see months and weeks go by and to note that we still have so many things to clarify.

I am certain that your personal influence will help us overcome the last obstacles and ensure that the concert results in a great success.

Very sincerely

Igor Strawinsky

Details of the substitution of the piece by Gesualdo with a work by Giovanni Gabrieli, as suggested by Piovesan in a letter of 5 February 1956, can be found in a letter sent by the composer to Piovesan on 3 March 1956 (Appendix Figure A7). But the problems were not entirely over. Now that the question of the length of the Canticum had been resolved thanks to the good will of both parties, two more dark clouds were gathering on the horizon that were to take them only a step away from the complete breakdown of discussions. Firstly the definition of the date of the concert, which Stravinsky had wanted to know right from the start, was late in coming due to a series of bureaucratic setbacks, including, perhaps, problems regarding the permission of the ecclesiastic authorities to use the Basilica. Secondly, Stravinsky wanted to share the conducting of the concert with Craft. Piovesan made no attempt to hide his concern and wrote to Roth: “[...] I'm worried about a possible fall in tone, given that the concert is supposed to be entirely conducted by Stravinsky. What do you think? I know that Stravinsky is very attached to his nephew [sic] Craft and I was thinking of letting Robert Craft conduct another concert in the Festival, so as to avoid creating any further troubles or misunderstandings. As always it is a question of money and meeting the needs of the Festival. I hope I can sort this one out too [...]". ${ }^{29}$

Such worries were once again shared by Roth, but it is Stravinsky who, in a telegram written in a firm and decisive tone, insists that the negotiations should be speedily concluded:

Unless I receive immediate telegraphic acceptance all points paragraph 2 my letter march 28 I am cancelling my voyage to Venice Stop You have avoided committing yourselves while I made all possible concessions situation must end - Stawinsky. ${ }^{30}$

The point of view of the Biennale is once again expressed with the usual tact by Piovesan in a draft of a letter dated 7 May, which the composer denies ever having received. In the letter Piovesan clearly states that "la Biennale préfèrerait naturellement que tout le concert dédié à la musique vénetienne, y compris votre programme, soit dirigé par vous-même”. ${ }^{31}$ Nevertheless, understanding Stravinsky’s reasons for asking Craft's participation, he then states his intention to look for a satisfactory solution. Unfortunately time was growing very short and the chances of setting up new funds to finance the involvement of Craft were poor. And neither did the alternative proposed by Stravinsky in a following telegram seem very satisfactory: «Your letter May seventh not received stop Accept conducting entire [sic] program but in Fenice only as follows Canticum Mass Canticum Bach Variations stop You must engage Craft for full rehearsals before my final ones stop Chorus soloists must be prepared before our arrival Awaiting cable acknowledgement = Stavinsky». ${ }^{32}$

\footnotetext{
${ }^{29}$ ASAC, from the Italian version of the letter from Piovesan to Roth dated 14 April 1956 and marked "please translate into English”.

30 ASAC, telegram from Stravinsky to the Biennale on 6 May 1956.

31 ASAC, copy of the letter from Piovesan to Stravinsky dated 7 May 1956.

32 ASAC, telegram from Stravinsky to the Biennale on 17 May 1956.
} 
On hearing Roth's advice, ${ }^{33}$ Piovesan decided to accept Stravinsky's first proposal, where Craft was to conduct the first part of the concert. At last, after two years of discussion, the problems were finally resolved; it only took a few days to work out the last details and on 30 June, after receiving permission to use the Basilica, Piovesan was able to give Stravinsky confirmation of the date and place of the concert.

\section{Conclusion}

The historic reconstruction that has been attempted here provides an account of the events that took place between 1954 and 1956; events that led to the composition not of a Passion but of the Canticum. And yet apart from the curiosity value of the episodes surrounding a particularly problematic commission, the whole affair raises two interesting issues.

First of all, why did the composer change his mind about a project that had immediately met with such wide and enthusiastic approval? Setting aside for the moment any questions of a merely economic nature, which would only partially answer our query, one might consider the possibility of there not being enough time to write such a demanding composition. As it turned out, the piece in question was actually completed a good four months before the agreed date. As early as the end of November 1955 Stravinsky had informed Roth (in a letter dated 25 November 1955) that the work was almost ready, but he added that it was better not to tell the organizers in Venice. «Because Piovesan \& Co. are still worrying about the shortness of Canticum, I want to avoid any discussion as to the amount of work I have put into it. By working day and night and refusing a lot of engagements I have been able to complete my task in a few months less than originally scheduled, but this is my own affair. I will ask you to notify Piovesan on March 31, 1956, that you have received the completed work. In the meantime it will remain our secret» (Craft, 1982-85, vol. III, p. 395).

Another hypothesis could take into account the stylistic frame in which the Canticum was composed. It was written, together with the Three Songs from William Shakespeare and Agon, in a period when Stravinsky was experimenting with serialism. The use of such techniques should not, of course, lead us to suppose any sort of "conversion" to the musical avant-garde of Vienna; ${ }^{34}$ judging from the aspects of the system he was trying out, his intention was not to adhere to the "movement" whole-heartedly, but rather to absorb, integrate, and redefine the technique in the context of his personal style. His aim was to search for a balance between his own particular concept of music and what was at the time one of the most innovative techniques in composition. In the five sections of the Canticum such a balance is accomplished by adopting a highly symmetric formal plan. The first section corresponds to the fifth, which is none other than the retrograde of the first; the second and fourth sections are serial, and the third (which is also serial) consists of a cantata in three parts, featuring yet another palindromic symmetry: the central part is a dialogue between soloists and choir, while the outer parts

\footnotetext{
33 «[...] It seems that Strawinsky is adamant that he will not conduct more than the Canticum and the Bach Variations and I am afraid that we can do no more than comply with the request of the great man. I think you should not worry unduly about any possible effect on the public; Strawinsky has an extreme fascination for the public and the importance of the Concert would not be impaired if he conducts the Canticum and the Bach together after the interval so really concluding and terminating the Concert. If we do not accept this, I think we all would have an awful lot of trouble which should be avoided in the interest of all concerned [...]» (ASAC, letter from Roth to Piovesan dated 15 May 1956).

34 "Some journalists have rashly spoken of a conversion [...] But it should be understood that his flirtation with dodecaphony (even though, as we shall see, dodecaphony is really not the correct term to use) has personal motivations much deeper than those that normally prompt the tonal moths to flutter around the flame” (Mila, 1983b, p. 143).
} 
are canons sung by the choir. ${ }^{35}$

But the existence of such formal correspondences is not the only analytical finding to emerge from studies on the symmetries to be found within the Canticum. Palindromic serial structures were also identified by David H. Smyth when studying the sketches of the Canticum, while Akane Mori, in a issue of the Journal of Music Theory, has identified certain complex proportional structures in the fourth section, ${ }^{36}$ thus expanding on a most interesting theory proposed some years ago by Jonathan Kramer. In The Time of Music, New meanings, new temporalities, new listening strategies, published in 1988 and dealing with the temporal aspects of music, Kramer observed that the feeling of unity and coherence felt when listening to the music of Stravinsky was not only the result of the presence of common musical material, suitably elaborated during the course of the work, but also of a particular formal structure brought about by juxtaposing sections that while seeming to be independent from each other actually share a mutually proportional duration. That is,

Kramer believes the impression that the sections of a piece by Stravinsky end just at the right moment is not due to the exhaustion of the internal processes of the single sections, but has something to do with the relative tensions governing the whole score. In other words it could depend on the fact that the proportions take on a decisive role in the formal coherence of music where non-linearity is a dominant structural force. (Pozzi, 1995-96, II part, pp. 66-67) ${ }^{37}$

These analytical findings-findings that point yet again to the formal perfection so typical of Stravinsky that we also find in other sacred compositions, such as the Mass ${ }^{38}$-are of utmost importance in the understanding of the events we have described above. The presence of a highly organized internal symmetry as reported by Craft, Smyth and Akane Mori could explain why the composer was unwilling to add to or expand the sections originally foreseen, since this would have involved a formal and perhaps structural reorganization of the whole piece. As a consequence, not being able to meet the requests of the festival organizers for strictly musical reasons, Stravinsky was forced to find other paths to reach an agreement.

A second point to bear in mind is the businesslike precision with which Stravinsky carried out the negotiations for his commissions. His approach has been compared by some to that of Verdi and clearly underlines one thing: the professional attitude both composers applied to their work as musicians. On this matter it is interesting to read a piece written by Mario Labroca, composer, critic and organizer of the Biennale until 1972. Labroca retains unforgettable memories of his meeting with Stravinsky in 1925, during the Venice festival of that year:

[...] Stravinsky arrived in Venice armed with carefully drawn up contracts and this was how I first knew him. After that I had the pleasure of seeing him from time to time and concluding with him memorable agreements for performances of his works. I confess though that my inexperience as an organizer was the cause, in 1925, of a sad delusion: an abrupt

\footnotetext{
${ }^{35}$ A complete analysis of the score was carried out by Craft in the program notes for the concert in Venice. The piece was then translated and published in "The Score” (December 1956). See also: Craft-Mila-Piovesan, 1956; von Loeffelholz, 1968; White, 1983, pp. 582-592.

${ }^{36}$ On the proportional analysis of the music of Stravinsky see also: Kirchmeyer 1958 (probably the first broad study on proportionality in Stravinsky), Cone 1962 (about the first movement of the Symphony in C), Mostyn Williams 1973 (on Symphony in C, II and III movements), Prime 1984, Kramer 1986, Vinay 1987, Kielian-Gilbert 1993 (on the second of the Three pieces for String Quartet and the Soldier's march from L'histoire du soldat).

37 When speaking of the linear quality of a certain parameter Kramer means its consequentiality, its bearing a relationship with the events immediately surrounding it, whereas by non-linear quality he means the lack of consequentiality with the neighboring events, while still maintaining a relationship with the principals or structural trends governing the whole piece or a section of it.

38 "Stravinsky thus supports the symmetrical structure of the mass with the Credo, whichacts as a pivot, while the other four parts of the Ordinarium are arranged symmetrically around it according to their function of praise (Gloria and Sanctus) or supplication (Kyrie and Agnus Dei)” (Vinay, 1987, p. 163).
} 
end was in store for those romantic illusions that had been conjured up for us regarding the typical artist totally caught up in the fire of creation, tousle-haired and picturesque, interested only in his work, disdainful of commercial transactions, purposely setting himself up on the opposite pole to the world of business, a direct descendant of the reckless life of the bohèmiens, an easy instrument in the hands of the greedy impresarios, who obtained incredible wealth at his expense [...] Stravinsky, then, was in the midst of that gross and rich society roaming between Paris, London, New York and Rome; a society made up of those, from the grand world, showing interest in the matters of art, and that nurtured the likes of Picasso, Cocteau, De Falla and the then youthful Milhaud, Poulenc, Auric, etc. As always happens, such societies end up by considering the artists they protect as courtesans, when they are not actually considering them as jesters; Stravinsky did not stoop to such level of friends but established a relationship of equality with the world at large, when he was not actually exerting his sense of superiority over them. He accepted their hospitality but did not repay them with the performance of his music in the confines of the host's house; playing music was something governed by separate rules, a professional act and not a free gift. He passed through the fire without being burned, he lived in society but did not have a worldly lifestyle: he was the master of his own freedom and always defended it, and even when he made use of a musical language far from his personal tradition he used his freedom to reduce and transform it until it fitted comfortably into the nature of his own philology. (Labroca, 1959, pp. 118-120).

From this point of view too and despite the difficulties Piovesan and the organizers in Venice must have undergone, one should not underestimate the important contribution that Stravinsky made to the development of relationships between the musician and the commissioning body. He took full advantage of his superior status to impose his own deadlines and conditions, establishing a position for the musician in society that was in stark contrast to that perpetuated by what remained of the romantic world, or rather of the romantic idea of the musician.

\section{References}

AAVV. (1958). Piovesan. La Biennale di Venezia. Catalogo del XXI FestivalInternazionale di Musica Contemporanea (Piovesan. The Venice Biennale. Catalog of the XXI International Festival of Contemporary Music). Venezia: La Biennale di Venezia, 9-11.

Cone, E. T. (1962). The use of convention: Stravinsky and his models. Musical Quarterly, XLVIII(3), 287-299.

Craft, R. (1982-85). Stravinsky: Selected correspondence edited and with commentaries by Robert Craft. London: Faber and Faber.

Craft, R. (1985). Dearest Babuskin: Selected letters and diaries of Vera and Igor Stravinsky (English translation from the Russian by L. Davidova). London: Thames and Hudson.

Craft, R., Mila, M., \& Piovesan, A. (1956). Le musiche religiose di Igor Strawinsky (The religious music of Igor Stravinsky). Venezia: Lombroso Editore.

Kielian-Gilbert, M. C. (1993). The rhythms of form: Correspondence and analogy in Stravinsky’s designs. Music Theory Spectrum, IX, 42-66.

Kirchmeyer, H. (1958). Igor Stravinsky. Zeitgeschichte im Persönlichkeitsbild. Grundlagenund voraussetzungen zur modernen konstruktionstechnik (Igor Stravinsky. History on personality profile. Foundations and prerequisites for modern technique of construction). Regensburg: Gustav Bosse.

Kramer, J. D. (1986). Discontinuity and proportion in the music of Stravinsky. Confronting Stravinsky. Man, musician and modernist. Berkeley: University of California.

Kramer, J. D. (1988). The time of music, new meanings, new temporalities, new listening strategies. New York: Schirmer Books.

Labroca, M. (1959). L'usignolo di Boboli (Cinquant'anni di vita musicaleitaliana) [The nightingale Boboli (Fifty years of musical italianlife)].Venezia: Neri Pozza Editore.

Malipiero, G. F. (1966). Igor Strawinsky a Venezia. Il filo di Arianna (Igor Stravinsky in Venice. Ariadne’s Thread) (pp. 195-198). Torino: Einaudi.

Mariani, R. (1976). Strawinsky a San Marco. Verismo in musica e altri studi (Stravinsky in San Marco. Verismo in music and other studies) (pp. 311-313). Firenze: Olschki.

Mila, M. (1983a). Canticum sacrum ad honorem Sancti Marci nominis. Compagno Strawinsky (Canticum sacrum ad honorem Sancti Marci nominis. Stravinsky companion) (pp. 149-152). Torino: Einaudi. 
Mila, M. (1983b). Il Settimino 1953 e i Three Songs from Shakespeare. Compagno Strawinsky (The Settimino 1953 and Three Songs from Shakespeare. Stravinsky companion) (pp. 143-148). Torino: Einaudi.

Mori, A. (1997). Proportional exchange in Stravinsky’s early serial music. Journal of Music Theory, Fall, XL(2), 227-259.

Mostyn Williams, B. (1973). Time and the structure of Stravinsky’s Symphony. C. Musical Quarterly, LIX(3), 355-369.

Parente A. (1956). Il Canticum in onore di S. Marco (The Canticum in honor of St. Mark). Gazzetta Musicale di Napoli, September, II(9), 141-144.

Piamonte, G. (1968). Ricordo di Alessandro Piovesan (Remembrance of Alessandro Piovesan). Nuova Rivista Musicale Italiana, November/December, II(6), 1061-1063.

Pozzi, E. (1995-96). L'analisi proporzionale della musica. Progetto per una bibliografia critica (The proportional analysis of the music. Project for a critical bibliography) (Diploma Thesis, Conservatorio di Musica S. Cecilia, Roma).

Pozzi, E. (1999). Catalogo della Biennale Musica 1999 (Catalogue of the Music Biennale 1999). Venezia: La Biennale di Venezia.

Prime, D. G. (1984). The clarinet in selected works of Béla Bartók and Igor Stravinsky. University of Wisconsin-Madison, DMA treatise.

Smyth, D. H. (1997). Stravinsky at the Threshold: A sketch leaf for Canticum Sacrum. Mitteilungen der Paul Sacher Stiftung, März, $X$, 21-26.

Vinay, G. (1987). Stravinsky neoclassico: L'invenzione della memoria nel '900 musicale (Neoclassical Stravinsky: The invention of memory in the music of the twentieth century). Venezia: Marsilio Editori.

Von LoeffelholzK, F. (1968). Igor Strawinskys Canticum Sacrum. Neue Zeitschrift für Musik, CXXIX, 168-176.

White, E. W. (1983). Stravinskij. Milano: Mondadori (Orig. Tit.: Stravinsky. The composer and his works). London: Faber and Faber. 


\section{Appendix A}

Havana, Cuba

April 6, 1953

Air Mail

Hon. Prof. Giovanni Ponti

President

Eenniale di Venezia

Venice, Italy

Dear Professor Ponti,

Thank you very much for your very kind letter of March 3I, 1953.

I am very glad to hear that the Venice Festival will give my "CANTATA".

As to my "SEPTEP" first of all I must confess that it is not quite completed yet, and being engaged on a tour at this time $I$ dare note guarantee when $I$ will finish it.

I will be back home in California the first days of June. At that time I will be in a better position to advise you on this matter which is as musch of interest to me as to the Venice Festival.

With best wishes for the success of your coming season,

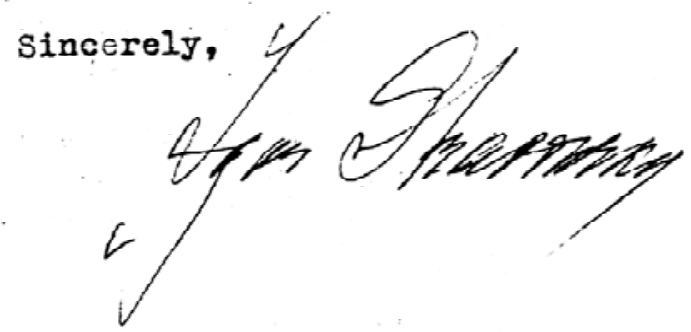

Figure A1. April 6, 1953, from Stravinsky to President Giovanni Ponti. 

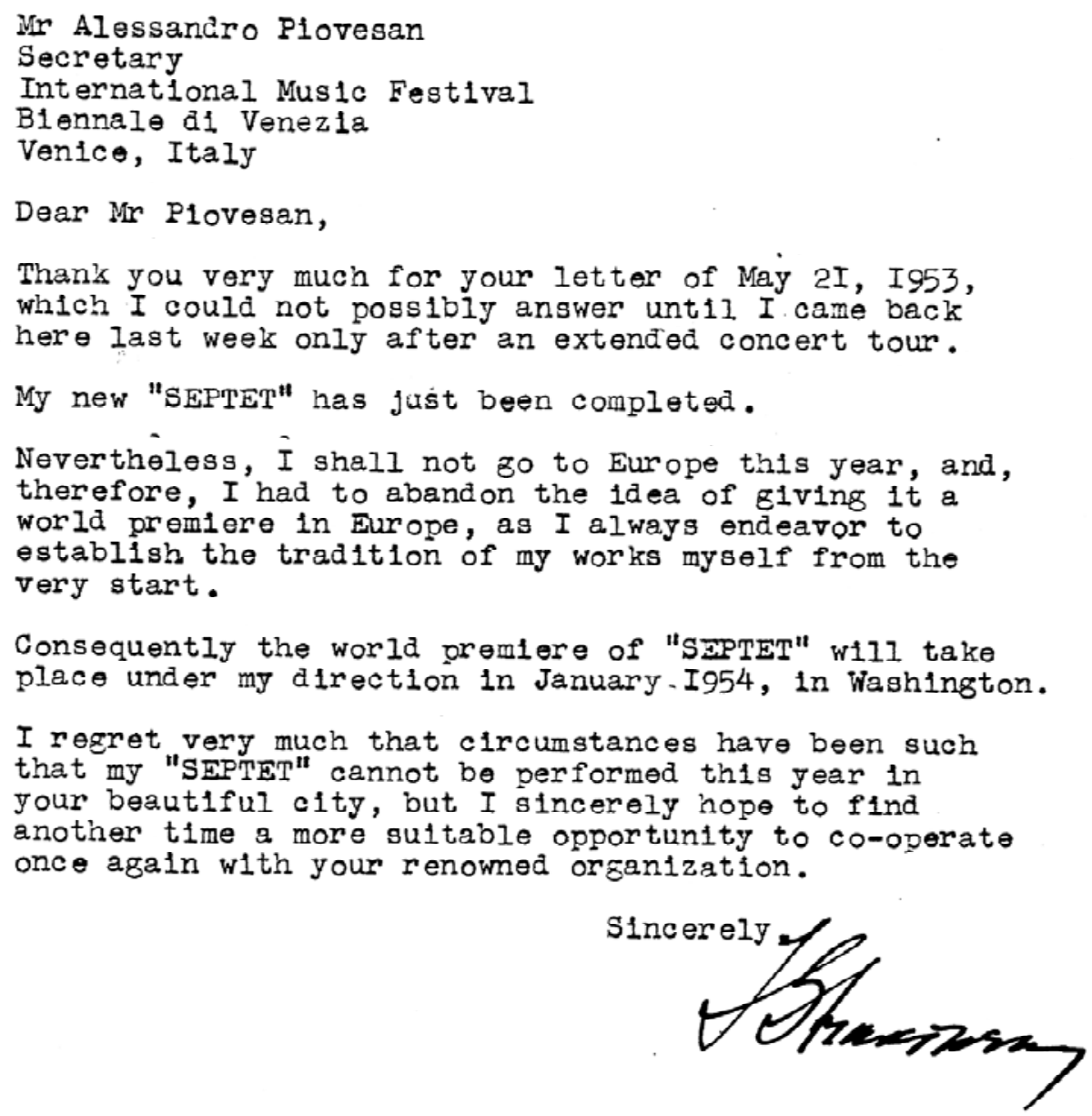

Figure A2. June 13, 1953, from Stravinsky to Alessandro Piovesan. 


\section{NORTH WETHERLY DRIVE}

HOLIYWOOD 46, CALIFORNIA
Le 2 I Ju1n I954 Par Avion

\author{
Monsleur Alessandro Plovesan \\ Directeur \\ Festival International de Musique \\ La Biennale \\ Ga' Giustinian \\ Ventse, Ital1e
}

Cher Monsieur,

Je viens de rentrer chez mol au terme de ma tournee de concerts on Europe et ce n'est que mantenant que je suls en mesure de repondre a votre almable lettre du I3. Ma1. Comme je vous l'al dit verbalement au cours de notre rencontre a Rome, votre projet d !un concert avec ma participation dans la Baslilque st. Marc a Venise sous les ausplces de la Biennale; m'interesse vivement. Prenant en consideration ce que nous avons deja esquisse, c'est-a-dire un programme comprenant une premiere partie consacree a une-ouvre de Gabriell1 (sous la direction de Robert Craft) et une deuxleme partie presentant au public une nouvelle oeuvre de mo1 (sous ma propre direction), j'envisagerais de composer pour cette clrconstance une oeuvre de 30 a 40 minutes (comme vous-meme I'indiquez) sur un texte des Ecritures (Ancien ou Nouveau Testament). Cette oeuvre seralt pour choeur, solistes, et differents instruments courants, ma1s ne necessitera1t pas necessairement un orchestre symphonique complet.

Je composerais cette oeurre pour la Biennale a qui elle serait dediee. L'aspect financler de ce projet se presenterait comme sult:

I/- Le cout total de cette commande pour la Blennale s'eleverait a $\$ I 2,000 .-\infty$ (payables aux USA on Dollars) et dont le reglement se ferait on 2. temps:

a/- un premier versement de $\$ 6,000$, - avant le Ier Octobre I955, et prealablement a la $\mathrm{mlse}$ en route de mon travall pour laquelle je reserveral cette date;

b/- un deuxleme et dernier versement de $\$ 6,000 . .-$ le Ier Aout I956 en contre partie de la l1vraison par mes solns de I'oeurre terminee a mon editeur, Boosey \& Hawkes.

2/- Ie prix de \$I2,000.-- c1-dessus Indique s'applique uniquement a la commande et ma direction a la Biennale de Venise en Septembre I956 devra faire l'objet d un cachet spec1al de $\$ 3,000 .-$ (payables aux USA en Dollars) prealablement a liexecution pubilque.t

Je vous prie de bien vouloir éxaminer ce projet avec les personnalites interessees et de me falre savoir des que vous le pourrez. s! 11 vous est agreable car, commejje vous $I^{\prime} a 1$ dit., j'al un programme de trava11 si charge que je do1s des maintenant arreter ses detalis meme 2 ans a parance.

Je vous prie de blen voulolr agreer, cher Monsieur, l'expression de mes sent lments les mellieurs.

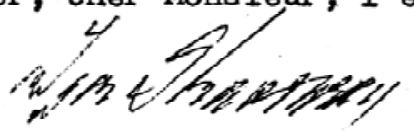

Figure A3. 21 Juin 1954, from Stravinsky to Alessandro Piovesan. 
Mr Alessandro Plovesan

Director

Festival International de Musique

La Biennale

Ca' Giustinian

Venice, Italy

Dear Mr Plovesan,

Thank you for your letter of October 30, I954.

I am still hoping as well as you do that your plans will get final approval in Rome.

As far as I am concerned the situation is as follows.

For the time being I am working on a commission for a new ballet for Ballanchine's New York Clty Center Ballet. Th1s w1ll be premiered next season.

For Venice it is true that I have in mind something connected with St liark, elther a Passion or Sacred Cantata. But I will not decide anyting unt1l I recelve the commlssion and, to be frank, commission and contract will have to be forthcoming before I complete my ballet.

As soon as my ballet will be completed I will start composing for another commission to be chosen among the many pressing proposals I have on my desk.

Because I like your ldea very much I would be glad to give you my preference but this means that we ought to know exactly where we stand within a few months.

W1 th all best wishes to you and the Blennale,

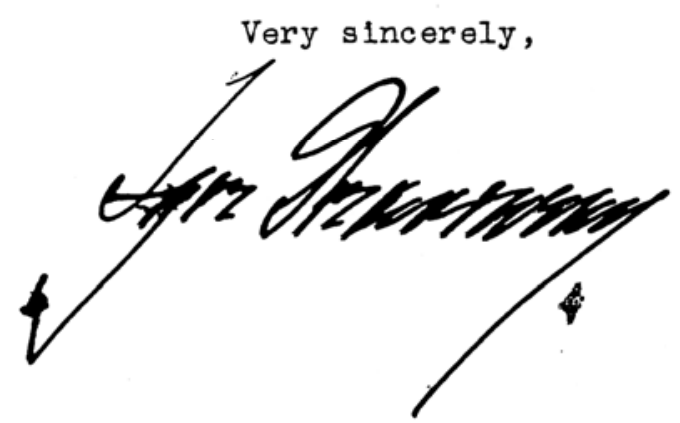

Figure A4. November 5 1954, from Stravinsky to Alessandro Piovesan. 


\section{NORTH WETHERLY DRIVE}

HOUYWOOD 46, CALIFORNIA

Le 4 Decembre I954

Par Avion

Monsleur Alessandro P1ovesan

Directeur

Festival International de Musique

La Biennale

$\mathrm{Ca}$ ' Giustinian

Venise, Italie

Cher Monsieur,

Je viens de recevolr votre almable lettre du 29 Novembre et suls heureux de volr que non seulement vous partagez mon 1dée de composer une "Passion Selon Saint Marc" (sur le texte latin de I'Evangile) mals que les differentes personnalités auxquelles vous avez soumis ce projet semblent egalement l'avolr à coeur.

Convenons donc des maintenant que c'est cette "Passion" qui dolt faire l'objet de vos negociations et de notre. contrat eventuels.

Evidemment je ne peux pas vous aonner a l'improviste des detalls sur une composition de cette importance mais dans les grandes lignes soyez assuré que l'orchestre sera modeste (commo vous savez, je fals de molns en molns de 1 "orchestre" et de plus en plus de la musique de chambre). Pour les solistes et le choeur rien ne depassera des limites très raisonnables.

Avec tous mes mellleurs souhalts pour le complet succes de vos negoclations aupres des organismes interessés, je vous exprime, cher Monsleur, mes sentiments les mellieurs.

P.S.

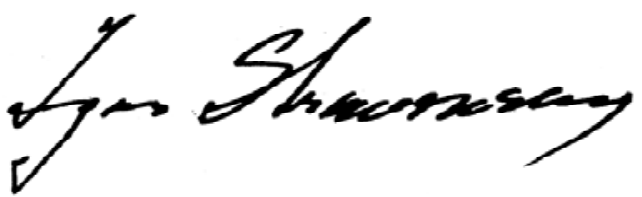

Si ce projet se realise 11 me sera particulierement agreable de dedier cette oeuvre simultanement a la Ville de Venise et a la Blennale

Figure A5. 4 Decembre 1954, from Stravinsky to Alessandro Piovesan. 
Mr Massimo Alesi

President

The Blennale di Venezia

Venice, 1taly

Dear Mr Alesi,

Thank you for your letter of June 30, 1955 .

W1th reference to the rad10 broadcasting rights of the premiere performance of the work you have commlssioned from me, and with reference to my letter of June 25, 1955, I w1sh to clarify some misunderstanding.

It is indeed 1mpossible to write in our contract anything conflicting with or jeopardizing the rights of my publisher, and doing so would amount to sell you something that I do not own.

For the same reason there is no ground for my being held responsible of something outside of my control.

Indeed, I went personally as far as I could by claiming no special compensation for the broadcast in addition to my conducting fee of $\$ 3.000 .--$ provided sald broadcast w1ll be done within one month from the date of the premlere live performance.

I do not see why you do not enter into 1mmediate negotiations with Dr Roth, of Boosey \& Hawkes Ltd, London, in order to settle this matter w1th him on an advanced bas1s. Dr Roth is most understanding and when I saw him in Europe three months ago I advised him of the state of our negotiations,

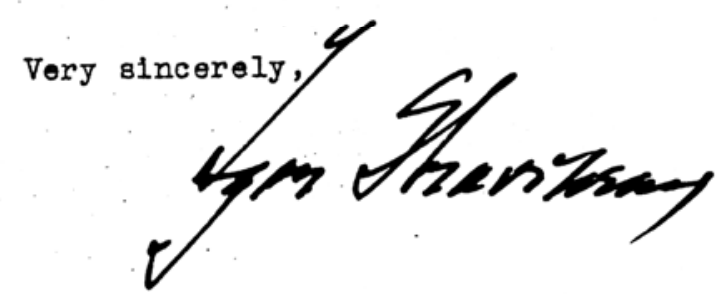

Figure A6. July 9, 1955, from Stravinsky to President Massimo Alesi. 
1260 NORTH WETHERLY DRIVE

$\operatorname{March} 3 / 56$

HOLIYWOOD 46, CALIFORNIA

Mr. Alessandro Plovesan

La Blennale di Venezla

Ga Glustinian

VonicE, Italy

Dear Mr. Plovesan,

About two weeks ago I recelved your cable of February 17th. Unfortunately inspite of your confirmation that the "SIXTHQUSAND DOLIARS ALREADY TRANSFERRED, my bank has not recelved the money.

Now I recelve your letter of February 24 and $I$. am answering you about the program, singers and the date of my concert.

1) The date of my concert must not be later than September 20th because, as you probably know from Mir. Erich Winkler, I am conducting a concert in Montreux (Switzerland) on September 25 with three days of rehearsals before.

2) The program I give you here in deta1ls is composed of works by Andrea Gabrleli, Glovannl Gabrleli (in replacement of Gesualdo as you asked me to do $1 t$ ), Monteverdi, Shustz, my GANTICUM SACRUM, (repeated after 1ntermission) and Bach (1n my arrangement):

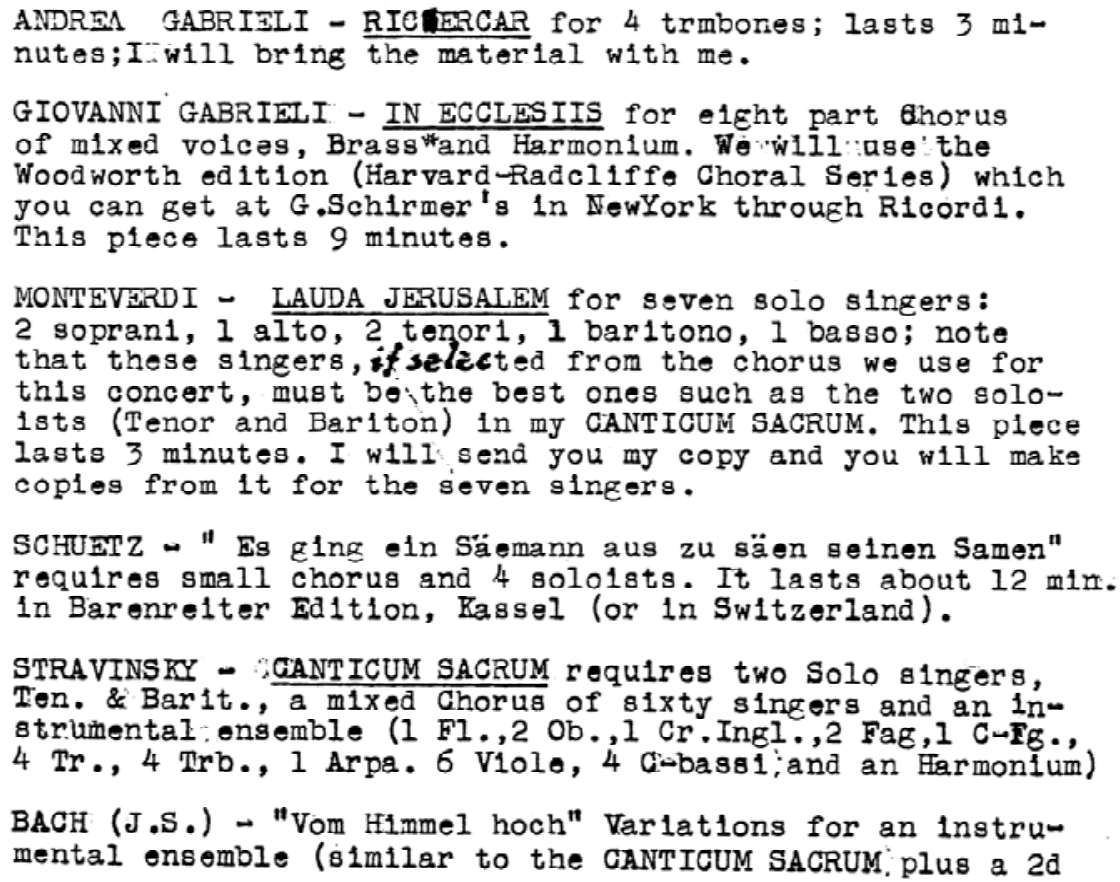

BACH (J.S.) - "Vom Himmel hoch" Varlatlons for an Instrumental ensemble (similar to the GANTICUM SACRUM plus a $2 \mathrm{~d}$

\section{क) 3 trumpets and 3 trombones}

Figure A7 (part I). March 3, 1956, from Stravinsky to Alessandro Piovesan. 


\section{$-2-$}

1260 NORTH WETHERLY DRIVE HOLUYWOOD 46. CALIFORNIA

Flute) and a mixed Chorus of about 30 singers. This plece in my instrumental arrangement must not be announced as a premlere because I am golng to "try 1t out" here in May.

3) For the solo singers (tenor bariton) of my CANTICUM please consult Rosbaud and Scherchen - both experlanced in the kind of vocal problems this mus1c presents; in other words, I need singers with e1ther perfect pitch or perfect relative pitch.

For the two sopran1 of Schuetz and Monteverd1 I would suggest Magda Laszlo and a young American soprano who w1ll be in Europe at that time - M1ss Mar1lynn Horne, 2951 Pacific Avenue, Long Beach 6 , California.

For the Chorus of my CANTICUM I need 60 singers. Torino is reputed to have the best chorus in Italy and I need 1t for my work.

Dr. E.Roth wrote me that you have not got sufficient funds for a separate concert for Robert Craft. In this case I advise you to engage him to conduct in my concert the two Gabrielis, Schuetz and Monteverd1. He can be very helpful as well, therefore, in allowing me to concentrate on my CANTICUM and my Bach Varlations. I am sure you w1ll offer him an acceptable fee.

\section{REHEARSAIS}

before I arrive.

a) Naturally the sololsts and chorus must knowthe music

b)We w1ll need rehearsals with the sololsts and the chorus before starting the instrumental ones.

c) For CANTICUM and Bach I w1ll need at least three rehearsals - Instruments with sololsts and chorus - but this number of rehearsals depends on the quality of the instrumentalists - please, tell me what orchestra exactiy it will be this year?

d) I am very concerned about the bass trumpet and the contra bass trombone (as in Wagner's RING) both of which instruments have a very important parts in my CANTICUM. Kindly reassure me on this subject.

I think that $1 \mathrm{~s}$ enough for today. I will greatly appreclate an early reply on this letter.

W1th best wishes

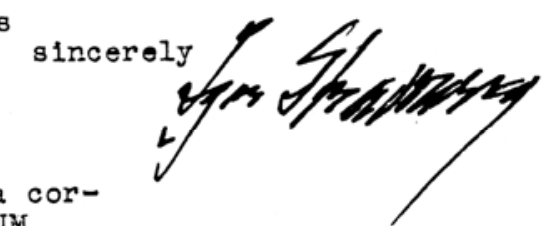

P.S.

In a few days Dr. E.Roth w1ll send you a corrected proof of the vocal score of my CANTICUN. As soon as you will have it be kind enough to tell your President about it in order to release the $\$ 6000$ - which my bank at that time, let us hope, w1ll be in possession of.

Figure A7 (part II). March 3, 1956, from Stravinsky to Alessandro Piovesan. 


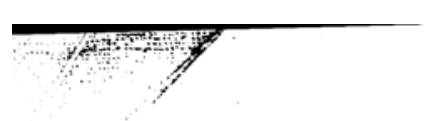

Mr. Lie President de la

BIRNNALE de Venise

Comte Massimo Alesi

Venfse, Italle.

Hillywood,

1. 28 mars,1956

Mon cher Comte,

Votre lettre du 14 mars vient seulement de parvenir 1c1. Son contenu revel que nous sommes en grande partie $d^{\prime}$ accord. Cependant 11 semble necessalre que nous nous entendions une fols pour toutes sur les points sulvants:

1- In ce qui concerne le premier payement (1e $1-e r$ avr11) 11 vous reste a ecrir d irgence au directeur de la Bank of Amer1ca, Sunset-Glark branch on lul donnant vos instructions formelles (en anglais) afin qu'tl effectue le payement des fonds a mon propre compte des. leur arrivee 1c1. A defaut do ces instructions la somme resterait bloquee en depot et garantie ce qui n "est plus conforme aux termes de nos nouveaux accords.

2- En ce qui concerne le payement du solde, je trouve que votre demande d'attendre jusqu'au moment de 1 "execution est exessive. In effet, la somme alors en calise ne correspond pas a mon cachet (puisque jo vous fais desormals cadeau de ma direction) mals au complement du prix de la commande. Cependant je comprends votre situation vis-a-vis du Consell d Administration et $j e$ vous propose le compromls sulvant: a) vous vous engagez a Inviter Robert Graft et a lul payer $\$ 400 .-$ pour qu"1l dirige dans mon propre concert la musique dos maltres anciens. Alns je me reserveral strictement pour mon propre CANTICUM SACRUM et pour ma transcription de Bach. b) En echange de quol graccepterai que lo payement final me solt remis dix jours avant la date de mon concert. c) Ce concert n'aura pas lieu plus tara que le 20 septembre et la date exacte devra m en etre donnee le 15 avril au plus tard.

Ayez I'obligeance, mon cher Comte, me repondre a'd plus vite car je vous avoue que je suis impressionne de volr passer mols et semaines et de constater que nous avons encore tant de choses a mettre au point.

Je suis certain que votre influance personelle nous a diera a surmonter les derniers obstacles ot a falre du tout uno grande reussite.

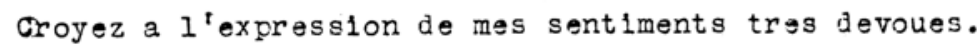

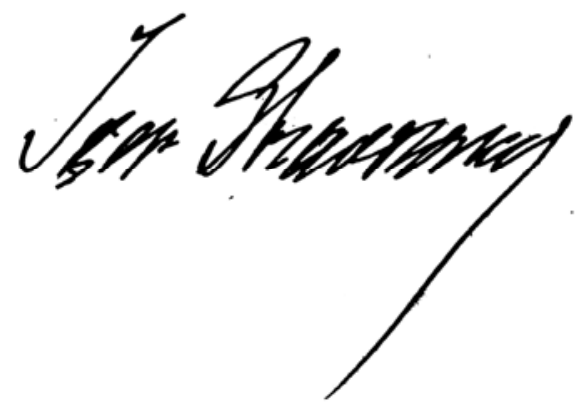

Figure A8. 28 Mars 1956, from Stravinsky to President Massimo Alesi. 